$\boldsymbol{\nabla}$ Artikkeli

\title{
Lippmann vai Dewey? Demokratia, poliittinen kulttuuri ja julkisuus'
}

\begin{abstract}
Walter Lippmannin ja John Deweyn välinen yleistä mielipidettä ja julkisuutta koskenut sananvaihto 1920-luvulla on muodostunut poliittisen viestinnän tutkimuksen maamerkiksi. 1980- ja 1990-luvulla, eritoten James W. Careyn vaikutuksesta, keskustelun osapuoliin alettiin suhtautua mustavalkoisesti: Lippmann nähtiin antidemokraattina ja Dewey demokraattina. Artikkelin tarkoituksena on korjata tätä näköharhaa. Lippmannin käsitys demokratiasta noudattaa Yhdysvaltain perinteessä federalistista ja Deweyn antifederalistista näkemystä. Lippmannin käsitys poliittisesta kulttuurista nojaa antiikin roomalaiseen ja Deweyn kreikkalaiseen kansalaisihanteeseen. Journalismin ja julkisuuden roolin Lippmann ja Dewey näkevät pääosin identtisesti. Molemmat korostavat joukkoviestinnän tärkeyttä yhteiskunnan tekemisessä näkyväksi ihmisille. Ainoa huomattava ero koskee lehdistön keskustelevaa luonnetta; Lippmannille se ei ole tärkeä, Deweylle on. Lopuksi tarkastellaan Lippmannin ja Deweyn välisen kysymyksenasettelun kestoluonnetta vertaamalla sitä yhtäältä Jürgen Habermasin ja Niklas Luhmannin erimielisyyteen yleisen mielipiteen funktiosta 1960luvulla, toisaalta poliittisen viestinnän tutkimuksen kolmeen nykyiseen päävaihtoehtoon.
\end{abstract}

AVAINSANAT: poliittisen viestinnän tutkimus, Lippmann, Dewey, demokratia, poliittinen kulttuuri

emokratian kriisi ja sitä ilmentävä julkisuuden rakennemuutos ovat puhututtaneet mediatieteilijöitä 1990-luvun ensipuoliskolta lähtien. Edellinen keskustelun huippu saavutettiin 1970-luvulla ja sitä edeltänyt 1920-luvulla. Nykyinen kysymyksenasettelu palautuukin siihen kahtalaiseen murrokseen, jonka massademokratia (yleinen äänioikeus) ja massaviestintä (laajalevikkinen kirjallisuus, massalehdistö ja elokuva) toivat 1900-luvun taitteessa mukanaan. Huomatakseen kuinka vähän ongelmatilanteemme on itse asiassa muuttunut tarvitsee vain katsoa sitä, minkälaiset teemat hallitsivat demokratiateoriaa sata vuotta sitten.

Demokratia pitää sisällään kansanvallan ja kansansuvereeniuden idean. Sen toteutuminen edellyttää ainakin kolmea seikkaa: kansalaisosallistumista, rationaalista maailmasuhdetta ja suuntautumista yhteishyvään (Schumpeter 1996, 250268). Vain kun kansa on riittävässä määrin poliittisesti aktiivista, arvioi toimintamahdollisuuksiaan järkiperäisesti ja pitää silmämääränään yleistä etua, se voi 
säilyttää vallan käsissään ja demokraattisen valtiomuodon pystyssä. 1900-luvun koittaessa kaikki nämä ehdot koettiin kuitenkin uhatuiksi, mikä sai ilmaisunsa vuosisadanvaihteen politiikan teoriassa, osana sitä Walter Lippmannin ja John Deweyn yleistä mielipidettä ja julkisuutta koskeneessa sananvaihdossa 1920-luvulla.

Ensinnäkin massademokratia, kansanvallan toteutus miljoonien ja kymmenien miljoonien ihmisten valtioissa, synnytti modernin puoluelaitoksen. Puolueet kokoavat ja kanavoivat kansalaisten aktiivisuutta, mutta ne myös korvaavat sitä. Kansanpuolueissa korostuu edellinen, vaalipuolueissa jälkimmäinen seikka. Kummassakin tapauksessa puolueista tulee koneistoja, jotka pyrkivät monopolisoimaan poliittisen aktiivisuuden. Näin pelkästä äänestämisestä uhkaa tulla kansalaisten enemmistön ainoa side poliittiseen järjestelmään. Kehitystä tukee toiseksi massaviestintä. Koska puolueet ja poliitikot voivat puhutella kansalaisten suurta yleisöä vain joukkoviestinnän kautta - näin sitä enemmän mitä enemmän kansanpuolueet muuttuvat vaalipuolueiksi - ne joutuvat sovittamaan sanansa sen vaatimaan asuun. Toisin sanoen rationaalinen argumentaatio pyrkii sovittumaan siihen ainoaan muotoon, joka Aristotelesta seuraten soveltuu kansanjoukon puhutteluun: retoriikalle tyypillisiin menettelytapoihin. Niiden mallina 1900-luvulla ovat taas yhä enemmän mainostekniikka ja PR-toiminta, siis manipulaatio ja propaganda. Kolmanneksi ei ole itsestään selvää, että poliittisten puolueiden mielikuvatehtailun avulla synnyttämä kannatus toteuttaa yhteishyvää. Puolueista tulee organisaatioita ja poliitikoista politiikan eliittiä, joka pyrkii pitämään itsensä vallassa tapahtui mitä tapahtui. Näin poliittiset ryhmäedut uhkaavat irtaantua yhteiskunnan yleisestä edusta.

Kansalaisten poliittinen passiivisuus, äänestäjiin vaikuttaminen yksinkertaistavan retoriikan keinoin ja politiikan eliittiluokan olemassaolo olivat niitä tekijöitä, joiden jo sata vuotta sitten - Gustave Le Bonista Max Weberiin ja Vilfredo Paretosta Robert Michelsiin - katsottiin tekevän demokratian klassisen kansanvallan idean toteutumisen vaikeaksi, ellei mahdottomaksi (Bellamy 2003). Lippmann laati aihepiiristä 1920-luvun ensipuoliskolla joukon kirjoituksia, joihin Dewey vastasi ensin lyhyesti, sitten perusteellisemmin. Lippmannin keskustelunavauksena voidaan pitää hänen Liberty and the news -kirjastaan vuodelta 1920. Siinä Lippmann käsittelee kokoavasti ongelmia, joiden varaan hänen kaksi vuotta myöhemmin julkaisema joukkoviestintätieteellinen pääteoksensa Public opinion nojaa. Dewey arvosteli teoksen tuoreeltaan, mutta vasta Lippmannin The phantom public vuodelta 1925 sai hänet reagoimaan tällä kertaa kirja-arvostelun lisäksi myös luentosarjalla, joka ilmestyi The public and its problems -nimisenä teoksena vuonna 1927. Tämä korpus (Lippmann 1922; 1925; 2008; Dewey 1922; 1925; 1954) muodostaa jatkossa lähemmän analyysini pääkohteen.

Tavoitteeni on kahtalainen. Yhtäältä pyrin osoittamaan, miten ongelmatilanteemme - ainakin kun on kyse joukkoviestinnän ja demokratian suhteista - alkoi satakunta vuotta sitten. Siksi käsittelen Lippmannin ja Deweyn sananvaihdon lisäksi lyhyesti myös heidän keskusteluteemojensa myöhempiä vaiheita. Toisaalta haluan tasapainottaa Lippmannin ja Deweyn nykyarvostusta, varsinkin media- ja joukkoviestintätutkimuksessa. Mikään salaisuushan ei ole, että 1990-luvun Dewey-renessanssin kääntöpuolena on alalla ollut lippmannilaisen demokratia- ja julkisuusteorian ankara kritiikki. James W. Carey (1992a; 1992b) suuntasi keskustelua tähän suuntaan jo 1970-luvulla ja 1980-luvun alussa, eikä hän näyttänyt sen jälkeenkään muuttaneen kantaansa (ks. Carey 1995; 1998). Careyn tulkintalinjaa jatkoi John Dur- 
ham Peters (1989a; 1989b), ja se on selvästi vaikuttanut käsityksiin niin Suomessa (V. Pietilä 1997, 117-127 ja 140-155; Kunelius 2004; 2006) kuin Yhdysvalloissakin (Asen 2003). On siten täysi syy avartaa näkökenttää. ${ }^{2}$

\section{Lippmann ja Dewey: kaksi reaktiota liberalismin kriisiin}

Lippmannin ja Deweyn väittely ajoittui ensimmäisen maailmansodan jälkeisiin vuosiin. Kumpikin yritti puheenvuoroissaan käsitellä omasta näkökulmastaan sitä demokratian ja julkisuuden muutosta, joka puhututti laajemminkin aikakauden politiikantutkijoita ja iduillaan olevaa joukkoviestintätiedettä niin Euroopassa kuin Yhdysvalloissakin (USA:n keskustelutilanteesta ks. esim. Aronowitz 1993). Sittemmin tätä historian taitekohtaa on kutsuttu yhtä hyvin suureksi muutokseksi, pitkän 1800luvun päättymiseksi kuin porvariston aikakauden lopuksikin. ${ }^{3}$ Sekä Lippmannin että Deweyn tulkintana oli, että 1900-luvun alkupuolen ongelmat juontuivat liberalismin kriisistä demokratian teoriana ja käytäntönä. Lippmann ja Dewey tarkastelivat kuitenkin liberalismin kriisiä eri suunnista, ja tämä vaikutti ratkaisevasti niin heidän analyysitapaansa kuin ajatuksiinsakin siitä, millä keinoin kriisistä päästäisiin.

Lippmannin mielestä klassinen Aristoteleelta periytynyt valtio-oppi, jonka premissejä 1600- ja 1700-luvun liberalismin filosofia oli jättänyt ennalleen, oli tullut tiensä päähän - perusnäkemys jonka hän omaksui jo ensimmäisessä, 24-vuotiaana julkaisemassaan teoksessa (Lippmann 1913). Tämän osoitti se, miten demokraattiset valtiot Yhdysvallat, Iso-Britannia, Ranska - kävivät ensimmäistä maailmansotaa ja varsinkin se, millä ehdoilla ne solmivat rauhan Versaillesissa. Lippmann oli Yhdysvaltain presidentin Woodward Wilsonin neuvonantajana, kun tämä valmisteli kuuluisat 14 artiklaansa sodanjälkeisen maailmanrauhan ohjelmaksi, joten hän puhui myös omasta kokemuksestaan. Lippmannin demokratiateoriaa maailmansotien välillä onkin selitetty sillä, että hän pyrki pukemaan sanoiksi Yhdysvaltain aktiivisen ulkopolitiikan periaatteita (Deppe 2003, 412-438). Lippmannin tavoite voidaan silti ymmärtää myös vähemmän funktionaalis-ideologisesti, yrityksenä käsitellä yhteiskunnan ohjauksen ongelmaa valtiojärjestelmässä, joka ei enää vastaa Aristoteleen politiikkakonseptiota. Ensimmäinen maailmansota ja Versaillesin rauhansopimus, joka nöyryytti Saksan ja kylvi pysyvän eripuran siemenen kansainvälisiin suhteisiin, osoittivat Lippmannille, että demokraattiset valtiot eivät kyenneet toimimaan oman pitkän tähtäimen etunsa mukaisesti. Tämän vuoksi ne olivat tuomittuja ajautumaan katastrofista toiseen. Lippmannin kysymyksenä vuosien 1920-1925 journalismi- ja demokratiakirjoituksissa voidaan siten nähdä se, kuinka valtiot ja niiden kansalaiset voivat ottaa oppia tekemistään virheistä, niin että liberalismin kriisi on ratkaistavissa myönteisesti. Kysymys ei ollut turha, sillä vuoden 1929 pörssiromahdus, Weimarin tasavallan tuho ja toinen maailmansota olivat vielä edessäpäin.

Deweylle liberalismin kriisi merkitsi puolestaan sitä, että individualismin periaate oli päässyt kalvamaan niin syvältä sosiaalisia siteitä, että aito yhteiselämä - poliittinen ja muu - oli käynyt mahdottomaksi. Dewey oli Lippmannia 30 vuotta vanhempi, syntynyt ennen Yhdysvaltain sisällissotaa ja siten elämänkokemukseltaan lähempänä sitä vanhaa Amerikkaa, joka väistyi uuden tieltä 1860-luvun ja ensimmäisen maailmansodan välisinä vuosikymmeninä. Tämä on vakiintunut henkilöhistoriallinen selitys Deweyn perusratkaisulle, yhteiskunnan tarkastelulle paikalliselämän sammakko- 
perspektiivistä. Se myös valaisee Deweyn ongelmaa, jonka muodostaa yhteiskunnan integraatio tekniikan ja talouden nopean muutoksen oloissa. Modernin yhteiskunnan tekniikan ja talouden kehitys on Deweylle sinällään hyvä asia, koska se lisää aineellista turvallisuutta. Ongelmana on kuitenkin se, että liberalistinen tekniikkaan ja kapitalistiseen talouteen nojaava yksilökeskeisyys atomisoi yhteiskuntaa. Koska taloudelliset intressit saavat aiempaa huomattavasti suuremman merkityksen valtion ohjauksessa, yhteisöjen hajoaminen on uhkana myös kansanvallalle. Deweyn keskeisenä pontimena vastauksessaan Lippmannille voidaankin nähdä sen uuden integraatiomuodon tapailu, joka vastaa koneiden ja suurteollisuuden aikakautta. Deweyn ydinajatuksenahan oli, että demokratian kriisi voidaan ratkaista vain lisäämällä demokratiaa. Maailmansotien välillä, jolloin epädemokraattinen valtiomuoto oli Euroopassa yleisin, kysymys oli mitä polttavin.

Lippmannin ja Deweyn näkökulmat täydentävät toisiaan, ja yhdessä ne kattavat tärkeän osan modernin yhteiskunta- ja valtioteorian kysymyksenasettelua. Lippmann kysyy, miten demokraattisia yhteiskuntia tulee hallita niin, että katastrofeilta vältytään, ja Dewey, miten tasavalloissa on turvattava sellainen yhteenkuuluvuus ja koheesio, että ne eivät muutu atomisoituneiksi harvainvalloiksi. Demokratian, poliittisen kulttuurin ja julkisuuden suhde näyttelee kummankin ajatusrakennelmassa keskeistä osaa. Yritänkin seuraavaksi katsoa hieman lähemmin Lippmannin ja Deweyn väittelyn antia näistä kolmesta suunnasta.

\section{Lippmann ja Dewey demokratiasta ja poliittisesta kulttuurista}

(1) Demokratia valtiomuotona merkitsee kansanvallan periaatetta. Kansanvallan idean toteutus riippuu kuitenkin siitä, miten kansa määritellään ja minkälaisissa muodoissa sen tahdon ajatellaan ilmenevän. Lippmannin ja Deweyn ajattelun perusero palautuu paljolti toisistaan poikkeavaan käsitykseen kansasta ja sen tahdosta, erityisesti valtiosta tahdon ilmaisijana. Lippmann ymmärtää kansan konflikti- ja Dewey konsensusteoreettisesti, kun taas valtiokysymyksessä Lippmann on realisti ja Dewey kallellaan liberalismiin. Lähden liikkeelle jälkimmäisestä.

Lippmannin perusongelmana on se, miten demokraattiset valtiot kykenevät toimimaan rationaalisesti yhä monimutkaisemmaksi ja läpinäkymättömämmäksi tulleessa maailmassa. Ongelma muodostaa samalla realistisen politikan teorian klassisen kysymyksen (Waever 1998, 720-721): miten valtiot voivat toimia älykkäästi suhteellisen tietämättömyyden oloissa? Ensimmäinen maailmansota ja uutisjournalismin kehitys saavat Lippmannin suhtautumaan skeptisesti liberaalin valtio-opin ajatukseen, jonka mukaan poliittisen tahdonmuodostuksen tulee demokratioissa nojata yleiseen mielipiteeseen ja sen ilmaisemaan kaikkien yleiseen etuun. Lippmannille yhteiskunnallinen ja journalistinen kokemus osoittavat, että yleisenä mielipiteenä ilmenevä julkisuus ei suinkaan tuo enää esiin yhteistä hyvää, vaan heijastaa pikemmin yksilöiden tiedon puutetta ja ryhmäkohtaista oman edun tavoittelua. Siksi valtion (poliittisten toimeenpanoelinten) ja yhteiskunnan (politiikan yleisönä toimivien kansalaisten) suhde on koordinoitava uudella tavalla. Sen seurauksena kansan tahtoa valtiossa toteuttavat elimet (presidentti, hallitus, ministeriöt) tulee irrottaa yleisen mielipiteen liekanuorasta ja sitoa sen sijaan menettelytapoihin, joiden avulla ne voivat olla paremmin kosketuksissa maailman tapahtumiin. 
Lippmannin realistinen ratkaisu korostaa valtion itsenäisyyttä, kun taas Deweyn liberalismin kanssa yhdenmukainen kanta näkee valtion toissijaisena sosiaalisena muodostelmana. Valtio syntyy, kun ihmisten toiminnalla on yleisesti merkittäviä seurauksia, joita pitää säädellä. Primaaritasona Deweylle säilyvät paikallisyhteisöt, jotka yhteenliittymällä keskenään muodostavat valtion. Dewey $(1954,215)$ ilmaisee tämän Hegeliltä lainatulla kielellä hyvin painokkaasti: "Paikallinen on viime kädessä universaalia ja lähempänä absoluuttista kuin mikään muu." ${ }^{\prime \prime}$ Lippmannin näkemyksestä kanta eroaa siinä, että valtio saa sekundaarin luonteen: se syntyy alhaalta käsin ei yksilöiden välisenä sopimuksena, vaan yhteisöjen välisenä pyrkimyksenä hallita toimintansa ennakoimattomia seurauksia. Valtiosta tulee näin eräänlainen paikallisyhteisöjen jatke, sikäli kuin alhaalta tapahtuva ryhmänmuodostus pystyy tuottamaan välineekseen yleisön. Tämä ratkaisu selittää samalla Deweyn erikoista tapaa käyttää publictermiä sekä valtion, yleisen että julkisen merkityksessä (public-sanan monimerkityksisyydestä Deweylla ks. myös Renvall 2006). Näin valtio toimijana ja valtio yleisönä sekoittuvat keskenään, eikä poliittisen yhteiskunnan ja kansalaisyhteiskunnan suhde saa Deweyn demokratian ideaalissa sitä hahmoa, jonka Lippmann sille antaa.

Lippmannin ja Deweyn valtio-opin erot palautuvat heidän yhteiskuntakäsitykseensä, joka on Lippmannilla enemmän konflikti- ja Deweylla konsensuspainotteinen. Lippmannin näkemyksessä se, mitä me kutsumme kansaksi, koostuu toistensa kanssa hankauksessa olevista intressiryhmistä, niin että demokraattisen politiikan keskeisenä päämääränä on tuottaa tasapaino näiden voimien välille. Lippmannin Machiavellia vastaan Dewey asettaa Aristoteleen klassisen perinteen: demokratia on tapa, jolla poliittinen yhteisö ilmaisee oman identiteettinsä ja itsetietoisuutensa. Demokratia tarkoittaakin Deweylla samaa kuin yhteisöelämä, kansan elämä parhaimmillaan. Näinhän, kuten on yleensä ajateltu, Dewey pukee sanoiksi amerikkalaisen vakaumuksen demokratiasta uutena kansalaisuskontona. Ongelmana on Deweylle vain se, että modernin yhteiskunnan kehitys on vaikeuttanut tuotantovoimiensa tasoa vastaavien yhteisö- ja demokratiamuotojen löytymistä.

Joukkoviestinnän tutkimuksessa Lippmannin kantaa on varsin yksimielisesti pidetty elitistisenä ja Deweyn kantaa demokraattisena. Asia voidaan nähdä toisella tapaa, jos kysymys demokratiasta yhdistetään kysymykseen vakaasta hallitusmuodosta (vrt. Aristoteles 1991). Valaisen Lippmannin ja Deweyn ratkaisun eroa vielä tästä näkökulmasta, esimerkkinä kummankin tulkinta Yhdysvaltain valtiomuodosta. Tällä kertaa Lippmann on federalisti ja Dewey antifederalisti.

Yhdysvaltoja pidetään vanhimpana demokratiana, mutta mitä tarkoitetaan tällöin demokratialla? Lippmann (1922, 263-292) näkee Yhdysvaltojen poliittisen järjestelmän tuloksena kahden päätöksentekotason - liittovaltion ja osavaltioiden paikallisyhteisöjen - vaatimusten yhteentörmäyksestä. Perustanlaskijoista vahvaa liittovaltiota ajoivat federalistit (Adams, Hamilton, Madison), agraaristen paikallisyhteisöjen asiaa Jefferson. Federalistien keskeisenä tavoitteena Lippmannin mukaan oli luoda valtiomuoto, jonka avulla erilaisten etupiirien valta voitaisiin pitää tasapainossa. Tämä edellytti vastavallan luomista paikallisille valtakeskuksille, mikä synnytti niin sanotun checks and balances -periaatteen. Liittovaltion tasolla se johti Lippmannin tulkinnassa siihen, että edustajainhuone on ainoa demokraattinen elin, jonka valtaa tasapainottavat ei-demokraattista valtaa käyttävät senaatti, valitsijamiehistö (electoral college), presidentti vetooikeuksineen ja oikeuslaitos (erityisesti korkein oikeus). Se, että tosiasiassa monarkistisia piirteitä omaava valtiomuoto saatiin näyttämään suoran demokratian ihanteiden 
mukaiselta, tapahtui Lippmannille Jeffersonin ansiosta. Kehityksen vei päätökseen Jackson, jonka presidenttikaudella 1830-luvulla otettiin käyttöön poliittiset julkiset virat ja kaksipuoluejärjestelmä vakiintui. Deweyn kuvaus Yhdysvaltain demokratiasta käsittelee vain jeffersonilais-jacksonilaista puolta. Tyypillistä kyllä, Dewey (1922) ei Public opionionin arvostelussaan edes mainitse federalisteja, vaikka kirjoitus referoi muuten tarkkaan Lippmannin argumentaatiota. Deweylle (1954, 110-142) Yhdysvaltojen poliittinen yhteiskunta kehittyi aidon yhteisöelämän pohjalta. Se, että kehitys katkesi, ei hänelle johtunut liittovaltion ja osavaltiotason voimien tasapainottamispyrkimyksestä, vaan siitä, että liberalismi - individualismin periaate - sai 1800-luvun kuluessa niin tiukan otteen Yhdysvaltojen yhteiskunnasta. Sen vuoksi paikallisdemokratian voimat eivät enää riittäneet kontrolloimaan ja koordinoimaan kansanvallan käyttöä liittovaltion tasolla. Keskeisenä syynä tähän oli taloudellinen liberalismi, kapitalismi, joka alkoi vaikuttaa voimallisesti valtiolliseen päätöksentekoon.

(2) Kuinka syntyy demokraattisia ihmisiä, ja miksi inmiset antavat tukensa demokraattiselle hallintatavalle? Miten demokratiat takaavat yhteiskuntarauhan ja estävät kansalaissodan? Valtiomuotokeskustelua tulee täydentää kuvaamalla niitä keinoja, joiden varassa demokratiat pysyvät pystyssä ja joiden puuttuessa ne kaatuvat - pitiväthän politiikan asiantuntijat varsin yleisesti aina 1800 -luvulle saakka demokratiaa kaikkein lyhytikäisimpänä ja epävakaimpana valtiomuotona. Kysymykseen vastaaminen vie poliittiseen kulttuuriin ja julkisuuteen sen yhtenä osana. Lähden liikkeelle edellisestä.

Aristoteles (1991) katsoi, että eri ihmiset etsivät onnellisuutta eri tavoin, ja siksi valtiomuodot vaihtelevat. Kukin niistä taas pysyy pystyssä sille ominaisen luonnetyypin ansiosta, jonka jalostaminen edellyttää poliittista kasvatusta. Poliittisen kulttuurin käsitteellä on sittemmin pyritty tavoittamaan niitä subjektiivisia tekijöitä, joilla voidaan selittää sosiaalistumista demokraattiseen elämäntapaan, niin että inmiset pitävät demokratiaa legitiiminä poliittisena järjestyksenä (Almond 1989; Berg-Schlosser 1983; Pappi 1986). Lippmann ja Dewey ovat molemmat demokraatteja valtiomuotokysymyksessä, mutta he näkevät demokraattisen poliittisen kulttuurin eri tavalla. Ero vastaa suunnilleen liberalismin ja tasavaltalaisuuden (kommunitarismin) välistä jännitettä sellaisena, kuin se on ilmennyt viimeisen parin vuosikymmenen politiikanfilosofisessa keskustelussa (vrt. esim. Habermas 1996; 2003). Yksi näkökulma ongelmakenttään avautuu kansalaisuudesta käsin.

Länsimainen kansalais-käsite on velkaa kahdelle perinteelle: antiikin Kreikan poliittisen kansalaisuuden ja Rooman vallan ajan oikeudellisen kansalaisuuden periaatteelle (Pocock 1992; vrt. myös Nauta 1992). Aristoteleen muotoilussa edellinen nojaa jyrkkään eroon julkisen ja yksityisen elämänpiirin välillä, niin että yksityiselämä nähdään pelkästään julkisen kansalaistoiminnan ehtojen uusintajana ja sellaisena vähemmän tärkeänä. Tämän käsityksen kaikuja voi vieläkin kohdata ajatuksessa, että julkinen elämä ja poliittinen elämä ovat sama asia (tai ainakin antiikin poliksen tapaan miesten aluetta). Roomalaisessa perinteessä kansalaisuudella taas tarkoitettiin sitä toiminnan piiriä, jonka yksilölle avasi lain suoja, siis tietyn lakiyhteisön jäsenenä oleminen. Samalla kansalaisena oleminen merkitsi valtaa hallita esinemaailmaa, ei niinkään yhteenliittymistä muiden kansalaisten kanssa. Kansalaisuus tässä mielessä tarkoittaa siten valtion takaamaa yksilön oikeutta omistukseen ja sen kohteista nauttimiseen. Kyse on siis erosta, jonka muodostaa kansalaisuus nähtynä osallisuutena yhtäältä yleisen hyvän etsintään, toisaalta oman edun turvaamiseen. Saksan Bürger- 
sana sisältää nämä molemmat puolet; eron tekemiseksi on turvauduttava termeihin kuten Staatsbürger ja Gesellschaftsbürger (Habermas 2008, 141).

Lippmannin voi nähdä poliittisen kulttuurin kysymyksessä roomalaisena ja Deweyn kreikkalaisena. Toisin sanoen Lippmannille demokratian edellyttämä kansalaisuus hyveineen, joista demokraattinen poliittinen kulttuuri muodostuu, rakentuu yksilöiden erilaisuuden, ei samanlaisuuden varaan. Jo Aristoteles lähti siitä, että valtiot koostuvat aina erilaisista ihmisistä. Silti poliittinen yhteisö oli hänelle ihannemuodossaan mahdollinen vain, kun kaikki kansalaiset hyväksyivät ensisijaiseksi siteekseen kuulumisensa tiettyyn valtioon. Mutta näin osallistuminen hyvään elämään oli mahdollista vain julkisen toiminnan piirissä. Lippmann hylkää tämän aristoteelisen premissin ja hyväksyy valistushumanismin (ks. Taylor 1985) tavoin sen, että ihminen voi viettää hyvää elämää myös muilla tavoin. Siten hän tulee lähelle sosiaalidemokraattista käsitystä, jonka mukaan poliittinen demokratia on kuollut kirjain ilman yksilöille taattuja riittäviä elämän ehtoja. Demokratian henkeä pidetään yllä myös niin, että annetaan kansalaisille aineellisia ja henkisiä välineitä elämästä nauttimiseen. Ihmisen arvokkuus koostuu myös näistä asioista, ei vain poliittisen kansalaishyveen vaalimisesta.

Deweyn kreikkalaisuus on sikäli suhteellista, että myös hän hyväksyy modernin valitushumanistisen ihmiskuvan, esi- tai ulkovaltiollisen elämänpiirin tärkeyden. Hän esimerkiksi korostaa sitä, miten poliittiseen toimintaan osallistumista tukee kanssakäyminen ei-poliittisissa ryhmissä - kausaaliyhteys, jonka olemassaolo on saanut tukea empiiriseltä poliittisen kulttuurin tutkimukselta (Almond 1989). Demokratia on Deweylle ensisijaisesti elämänmuoto, johon kasvetaan paikallisyhteisöissä elämällä kasvokkaissuhteissa toisten kanssa, ja näin poliittisen toiminnan esipoliittiset muodot eivät kiinnity yksilöiden tavoitteenasetteluun yksilöinä. Päinvastoin kuin Hegel (1970), Dewey ei pane painoa sille poliittiselle kasvatukselle, jonka moderni kapitalistinen kansalaisyhteiskunta tuo mukanaan totuttaessaan inmisiä objektiivisuuteen ja universaalisuuteen, kun he joutuvat sovittamaan omat etunsa muiden etuihin. Moderni yhteiskunta ("Great Society") edustaa Deweylle vain kansalaishyveiden kannalta kielteisiä epäpersoonallisia suhteita. Demokratia opitaan kotona, tai sitä ei opita ollenkaan.

\section{Lippmann ja Dewey journalismista ja yleisön roolista}

(3) Julkinen viestintä on demokratian toteutumisen kannalta tärkeää molemmissa edellä käsitellyissä kohdissa. Se on tärkeää, koska kansan tahdon on tultava yleiseen tietoon ja vaikutettava päätöksentekoon ja koska kansan halua ja kykyä ilmaista tahtoaan - siis demokratian eetosta - tulee pitää yllä. Edellisessä tapauksessa julkisuus toimii kansan itseilmaisun, jälkimmäisessä poliittis-moraalisen kasvatuksen ja sosialisaation välineenä. Lippmannin ja Deweyn käsitys joukkoviestinnästä, eritoten yleisestä mielipiteestä eroavat toisistaan paljon vähemmän kuin nykykeskustelussa on usein nähty (hyvänä johdatuksena yleisen mielipiteen käsitteeseen ja suomalaiseen sanastoon ks. Suhonen 1998a; 1998b). Tämä johtuu siitä, että heidän analyysinsä sisältää lähisukuisia aineksia, jotka koskevat liberaalin demokratiakonseption umpikujaa ja julkisen viestinnän asemaa sekä kansan tahdonmuodostuksen että poliittisen toimintakyvyn ylläpitämisessä. Yritän osoittaa tämän tarkastelemalla ensin 
Lippmannin journalismi- ja yleisöteoriaa, sitten Deweyn yhteiskunnallisen tiedonvälityksen ja keskustelun teoriaa.

Lippmannille liberaalin demokratian kriisi ilmenee siinä, että lehdistö on ottanut parlamentin paikan yleisen mielipiteen keskuksena. Näin hallitus, siis vallassa olevat poliitikot, ei enää suuntaa toimintaansa pitämällä yhteyttä kansanedustajiin vaan lukemalla lehtiä. Joukkoviestinnästä on siten tullut poliittinen mahtitekijä, ei enää vanhan liberalismin mielessä valtion toimintaa kontrolloivana, vaan sen toimintaa ohjaavana instanssina. Toisin sanoen lehdistöstä on tullut suoran demokratian väline. Näin syntynyt tilanne on Lippmannille kestämätön, ei ainoastaan koska se rajoittaa toimeenpanovallan mahdollisuutta oman harkintansa käyttöön, vaan myös koska valtavirran journalismi ei voi toimia tämmöisenä välineenä. Syyt tähän löytyvät niin lehtien toimituksesta, uutisformaatista kuin lukijoistakin.

Modernin demokraattisen valtion kansalainen on riippuvainen joukkoviestimistä, koska vain niiden välityksellä hän voi olla yhteydessä siihen oman elämänpiirinsä ulkopuolella olevaan näkymättömään maailmaan, joka vaikuttaa häneenkin. Ollakseen vapaa toimimaan hän tarvitsee siten tietoa niistä asioista, jotka rajoittavat hänen toimintansa piiriä. Sanomalehti on tiedonlähteistä tärkein, koska vain sitä inmiset seuraavat päivittäin. Uutisten kykyä kertoa olennaisia asioita rajoittavat kuitenkin monet uutisen muotoon, lehtitalouteen ja lukijapsykologiaan liittyvät tekijät. Liberty and the news -teos luonnostelee Lippmannin journalismikritiikin peruskuvion, joka toistuu tietyn painopisteen muutoksin Public opinionissa. ${ }^{5}$ Nostan kritiikistä esiin joitakin pääkohtia.

Maailman kaikki toimittajat eivät kykene edes yhdessä kattamaan kaikkea sitä, mitä ympäri maailmaa tapahtuu. Tapahtuman onkin täytettävä tiettyjä ehtoja, jotta se tulee journalistisesti kiinnostavaksi ja taipuu uutisen vaatimusten mukaiseksi. Tapahtuman on muodostettava jonkinlainen katkos tapahtumisen yleiseen virtaan, ja sen käsittely on voitava standardoida tai stereotypisoida. Esimerkiksi huonoista työoloista tulee uutinen vasta, kun työntekijät käyvät lakkoon. Lakkoa taas käsitellään olettamalla, että asiassa on vain kaksi osapuolta, lakkoilijat ja työnantaja. Lippmannin mielestä toimittajat jatkavat näitä menettelytapoja periaatteellisista ja käytännöllisistä syistä. Periaatteellisena syynä on se, että modernissa yhteiskunnassa ei ole ylipäätään ymmärretty tiedon laadun ja demokratian toimivuuden välistä yhteyttä. Lehdistönvapaudessa ei ole kyse vain siitä, että liberalismin hengessä siedetään erilaisia mielipiteitä. Vielä tärkeämpää on, että luodaan keinoja yhteiskunnan, ei vähiten journalismin tietotason nostamiseksi. Edellistä käytännöllisempi syy vanhojen rutiinien jatkumiselle on toimittajien professionalismin puute. Ammatti, varsinkin riviuutistoimittajan työ on huonosti palkattua, pätevät koulutusväylät alalle puuttuvat, ja ammattikunnassa on vallalla kyynisyys, joka saa arvostamaan skuuppeja, muttei syvällistä asioihin paneutumista.

Lippmannin synkkää kuvaa oman aikansa yhdysvaltalaisesta journalismista tummentaa entisestään lehtiyritysten ja lukijoiden välinen suhde. Lehdet ovat kaupallisia yrityksiä, jotka myyvät tuotteitaan niistä maksaville. Näin niissä julkaistu aineisto on sellaista, jota juuri lukijat haluavat, eli se ilmentää maksavan lukijakunnan, ei yleistä intressiä. Ongelman kääntöpuolena on se, että lukijat haluavat päivittäisen uutispakettinsa mahdollisimman halvalla. Tämän seurauksena lehtiyritysten on rahoitettava julkaisua mainostuloilla. Näin syntyvät lehden kaksoismarkkinat: sanomalehti myy mainostajille lukijoidensa huomiota, ja se saa mainostajia pitämällä yllä sitä. Lukija- 
uskollisuuden luonti muodostaa siten tärkeän keinon, jolla lehti voi yrittää säilyttää suhteellisen itsenäisyytensä mainostajiin nähden. Se taas edellyttää, että lehti puhuttelee lukijoitaan tavalla, jonka nämä kokevat läheiseksi. 180o-luvun kuluessa amerikkalainen journalismi löysi Lippmannin mielestä tähän pari keinoa. Edellisessä lehti uhraa palstatilaa kertoakseen lukijoidensa mielipiteistä ja sattumuksista. Jälkimmäisen mukaan kaikkia asioita käsitellään mahdollisimman pitkälle draaman lakien mukaan ja melodramatisoinnin keinoin - siis painottaen intrigejä, konflikteja, tunteita. ${ }^{6}$

Sanomalehden ja sen lukijoiden vähäiset mahdollisuudet toimia suoran demokratian instrumentteina kiteytyvät lukijoiden asemaan yleisönä. Tämä muodostaa The phantom public -kirjasen pääteeman. Lippmann katsoo, että kansanvallan aktiivikansalaisen ihanne on johtanut siihen, että kansalaisten tehtävää yleisönä ei ole koskaan pyritty määrittelemään - saatikka että heitä olisi kasvatettu toimimaan yleisönä, siis poliittisen päätöksenteon ja politiikasta uutisoinnin seuraajana. Edellinen johtaa Lippmannin yleisön positiivisen funktion, jälkimmäinen journalismikasvatuksen kysymyksiin. Keskityn tässä edellisiin. Sille, että lehdenlukijat yleisönä eivät voi toimia suoran demokratian korvikkeena, on Lippmannilla kaksi pääsyytä. Ensimmäinen on se, että yleisöt muodostuvat aina jonkin käsitellyn kysymyksen ympärille, niin että kiinnostus kulloiseenkin aiheeseen ratkaisee yleisön laajuuden. Näin muodostunut yleinen mielipide vastaa vain ehkä hyvinkin pienen väestönosan näkemyksiä. Toisena syynä on yleisön toiminnan epäjatkuvuus, reagointi normaalista poikkeavaan. Yleisö korottaa äänensä vasta, kun yhteiskunnan toiminnassa ilmenee häiriöitä, siis kun muut instituutiot eivät kykene hoitamaan tehtäväänsä tyydyttävällä tavalla. Yleinen mielipide toimii näin Lippmannille politiikan näytöksen ulkopuolisena tuomarina, joka normaalioloissa hyväksyy näyttämön tapahtumat, mutta kriisioloissa tuo esiin kielteisen kantansa. Jälkimmäinen tehtävä ei ole aina helppo, ja siksi yleisön yhtenä tärkeimpänä tehtävänä Lippmannille on tukea niitä, jotka ensimmäisinä asettuvat vastustamaan mielivaltaista vallankäyttöä.

Lippmannin ja Deweyn kantojen suhteellinen läheisyys perustuu siihen, että heillä on kolme yhteistä premissiä. Molempien ongelmana on se, miten inmiset voisivat käyttäytyä älykkäämmin, niin että heidän toimintansa tuottaa toivottuja tuloksia ja siten - Aristoteleen mielessä - edistää hyvää elämää. Molemmat lähtevät myös siitä, että edellinen onnistuu vain, kun yhteiskunnat pystyvät kehittämään keinoja toiminnan välillisten ja siksi aluksi pimentoon jäävien seurausten havaitsemiseksi. Molemmat panevat lisäksi toivonsa siihen, että yhteiskuntatiede voi antaa ratkaisevan panoksensa näkymättömän maailman näkyväksi tekemisessä. Ensimmäinen kysymys koskee demokratian tavoitteita, kaksi muuta sen menetelmiä. Journalismin ja julkisuuden toiminnassa on kyse jälkimmäisistä. Yritän osoittaa, missä Deweyn ja Lippmannin ero varsinaisesti piilee.

Dewey on yhtä journalismikriittinen kuin Lippmannkin, joskaan ei yhtä yksityiskohtainen oman aikansa lehdistön ruotimisessa - hänhän ei ollut Lippmannin tapaan ammattitoimittaja. ${ }^{7}$ Deweykin lähtee siitä, että hallitseva uutisjournalismi on demokratian toiminnan kannalta täysin riittämätöntä. Hän ratkaisee pulman kuitenkin Lippmannista poikkeavalla tavalla. Vaikka Lippmannkin vielä Liberty and the newsissa pani paljon toivoa lehdistön toimintatapojen uudistumiseen sisältäkäsin, Public opinionissa ja The phantom publicissa hän siirsi painopisteen toisaalle. Demokratian uudistamisen keskeinen kysymys alkoi hänellä tarkoittaa ensisijassa julkisen sanan ja toimeenpanevan vallan suhteiden etäännyttämistä. Hallituksella tuli olla rauha toimia ei yleisen mielipiteen lyhytnäköisyyden ohjaamana, vaan tukeutumalla yhteiskuntatieteen tarjoamaan luotettavaan tietoon toimintaympäristön tilasta ja muutoksista. Myös Dewey hyväksyy sen, 
että rationaalinen toiminta on mahdollista vain tieteen tarjoamien välineiden avulla. Lippmannista poikkeavasti hän panee kuitenkin toivonsa siihen, että yleisön muodostavilla kansalaisilla on käytössä tosiseikkoja mielipiteenmuodostuksensa pohjaksi.

Demokraattisesti järjestäytyneen yleisön ehtona on Deweylla tieto; näin demokratia alkaa yhteiskunnallisella tiedonvälityksellä (vrt. myös Joas 1987, 616-617; Krüger 2007, 527). Tässä hän on puhdasverinen moderni valistusajattelija Lippmannin tapaan. Dewey ei kuitenkaan halua valistaa ensisijaisesti hallitsijoita vaan hallittuja - hänellähän näiden välinen kuilu on paljon kapeampi kuin Lippmannilla. Yhteiskuntatieteen tehtävänä on kertoa kansalaisille siitä näkymättömästä mutta vaikuttavasta maailmasta, joihin heillä ei ole yhteyttä arkielämässään. Lippmannin tapaan Dewey edellyttääkin, että aito yhteiskuntatiede painiskelee nimenomaan oman aikansa polttavien kysymysten parissa. Tiedolla, joka ei auta kansalaisia heidän yhteiskunnallisten ongelmiensa ratkaisemisessa, on vähän merkitystä. Näin kansalaisyleisön tarpeita palveleva yhteiskuntatiede edustaa käytännönläheistä soveltavaa, ei perustutkimusta. ${ }^{8}$ Näkymättömän maailman tekeminen näkyväksi on yksi asia. Toinen on sen kertominen kansalaisille muodossa, jota he ymmärtävät ja joka motivoi heitä toimimaan yhteisön etujen vaalimiseksi. Yhteiskuntatieteen lisäksi journalismi tarvitsee avukseen taidetta, esteettistä muodonantoa, joka pystyy pureutumaan kylmän faktamaailman läpi yhteiskunnallisten ongelmien inhimilliseen kaikupohjaan. Journalismiin liittyvä yhteiskunnallinen tiedonvälitys, joka ei kosketa ja motivoi inmisiä, jää vaille vaikutusta. Samaa Aristoteles väitti retoriikasta, julkisesta puheesta. Modernina ajattelijana Dewey vaihtaa klassisen, sääntöpohjaisen retoriikan taiteeseen, joka on tieteen ohella toinen tärkeä yhteiskunnallisen kokeilun ja keksimisen koelaboratorio. ${ }^{9}$

Deweyn mukaan demokratiaa siis edistetään julkisuuden keinoin levittämällä tieteellistä tietoa yhteiskunnan ongelmista ja esittämällä se taiteen keinoja hyväksi käyttävässä muodossa. Vasta tämän jälkeen kuvion keskelle astuu kansalaisyleisö, joka alkaa "väittelyn, keskustelun ja suostuttelun" (Dewey 1954, 208) menetelmin etsiä yhteistä etuaan kulloisessakin asiassa. Keskusteluvaihe ei ole edeltäjiään vähäpätöisempi, koska vasta siinä voi syntyä yhteiskunnallisia kysymyksiä käsittelevä yleisö - siis yleisö, joka pystyy muodostamaan yleisen mielipiteen. IIman yhteiskunnallista ongelmaahan, siis jotain yhteistoiminnan ennakoimatonta ja yleisesti häiriöksi koettua seurausta, yleisöä ei ole eikä sillä ole mitään tarvetta järjestäytyä valtioksi. Demokraattinen valtio taas syntyy Deweylla vain sitä kautta, että kansalaiset yhteen liittymällä ratkaisevat suhteensa koettuihin uhkatekijöihin ja päättävät siitä, mikä on yhteisön etujen mukainen tapa poistaa ne. Kun tämä voidaan toteuttaa koko modernin yhteiskunnan tasolla, se lakkaa olemasta persoonattomien suhteiden hallitsema "Great Society" ja muuttuu eläväksi "Great Communityksi". Näin vastaus liberaalin demokratian kriisiin on yhteiskunnan läpidemokratisointi ja radikalisointi (vrt. myös Dewey 1998a; 1998b).

Dewey yrittää yhdistää kolme erilaista käsitystä journalismista: informatiivis-objektiivisen, esteettis-kokeellisen ja kansalaisjournalistisen (ks. ensimmäisestä ks. V. Pietilä 1981; toisesta K. Pietilä 1980; kolmannesta Heikkilä \& Kunelius 1997). Niillä on kullakin eri funktio yleisön mielipiteenmuodostuksen kannalta. Informatiivis-objektiivinen journalismi tarjoaa yhteiskunnallisen ongelman kuvauksen, esteettis-kokeellinen liittää ongelman yleisön elämismaailmaan ja kansalaisjournalismi tuottaa ongelman praktisen ratkaisun. Dewey sanoo kirjassaan varsin vähän siitä, miten nämä kolme puolta liittyvät toisiinsa. Yksinkertaisin tapa olisi nähdä ne erilaisina journalistisina juttutyyppeinä, niin että journalistisessa kokonaisuudessa eläisivät rinnakkain informatiiviset, 
esteettiset ja keskustelevat ainekset. Haastavampaa olisi ajatella ne toisiaan läpäiseviksi, niin että sama juttu rakentuisi tiedonvälityksen, esteettisen muodonannon ja dialogisuuden aineksista. Joka tapauksessa on selvää, että Deweyn ero Lippmanniin koskee lähinnä vain sitä merkitystä, joka annetaan keskustelevalle lehdistölle tai deliberatiiviselle journalismille. Myös Lippmann oletti, että yleisöjen keskeisenä funktiona on erottaa yleinen etu erityisistä eduista, joskin hänellä yleisöt nousevat ja laskevat kuin meren aallot. Deweylla taas yleisöt ovat, tai niiden tulee olla, pysyviä, koska valtio rakentuu yhteisöelämälle. Tässä mielessä Lippmann on lähempänä liberalistista ja Dewey kommunitaristista ratkaisua.

\section{Lippmannin ja Deweyn väittelyn uusinta: nuori Habermas ja Luhmann}

Lippmann ja Dewey käsittelivät kiistassaan 1900-luvun demokratia- ja julkisuusteorian ydinkysymyksiä. Siksi on ymmärrettävää, että heidän 1920-luvun keskustelunsa sai seuraajia. Joukkoviestintätutkimuksen kannalta tärkeimpiä niistä on Jürgen Habermasin julkisuusteos ja sen nostattama debatti Länsi-Saksassa 1960-luvun lopulta 1970-luvulle (tiivistyksenä ks. Hohendahl 1978). Rekonstruoin kiistan uuden vaiheen siten, että Habermasin Strukturwandel der Öffentlichkeit (1962) jatkaa Deweyn ja Niklas Luhmannin (1970; ks. myös 1968) Habermas-kritiikki Lippmannin linjaa. Valaisen siten lyhyesti, miten 1900-luvun edetessä vastaus liberalismin kriisiin saa uusia muotoja.

Dewey ratkaisee modernin yhteiskunnan anomian ongelman traditionalistisesti. Toisin sanoen hän käyttää ei-anomisen modernin yhteiskunnan - "Great Communityn" - mittapuuna modernia yhteisöelämää sellaisena kuin hän katsoo sitä jeffersonilaisjacksonilaisen kansanvallan prisman läpi. Nuori Habermas arvioi tilannetta toisesta suunnasta, Hegelin porvarillisen yhteiskunnan teorian valossa (täydennän seuraavassa aiempaa Strukturwandel-tulkintaani: Malmberg 2004, 40-46; 2005; 2006). Habermas hyväksyy Hegelin (1970) tavoin, että porvarillisen yhteiskunnan historiallinen ainutlaatuisuus perustuu sen eriytymisen muotoon: perheen, kansalaisyhteiskunnan ja valtion alueisiin, joilla on kullakin oma toimintalogiikkansa. Habermas poikkeaa kuitenkin Hegelistä siinä, että hän Kantin inspiroimana sijoittaa julkisuuden kansalaisyhteiskunnan ulkopuolelle omaksi yhteiskuntakokonaisuuden neljänneksi instituutioksi. Samalla Hegelin kuvion voimasuhteet muuttuvat ratkaisevasti. Valtio ei ole Habermasin porvarillisen yhteiskunnan teoriassa enää kaiken keskus, vaan keskuksena toimii julkisuus, porvarillis-liberaali julkisuus. Se välittää valtion, kansalaisyhteiskunnan ja perheen suhteita, ja sen tehtävänä on myös taata uuden yhteiskunta- ja valtiomuodon sekä rationaalisuus että koheesio.

Porvarillinen yhteiskunta on kuitenkin vain ohimenevä vaihe, onnellisten historiallisten yhteensattumien tulos. Se ajautuu kriisiin ja hajoaa 1900-luvun jälkiliberaaliksi tai jälkiporvarilliseksi yhteiskunnaksi. Näin tullaan Habermasin tapaan vastata siihen analogiseen ongelmaan, jonka Dewey yritti ratkaista traditionalistisesti. Kun liberaalin yhteiskunnan perusta - valtion ja yhteiskunnan ero - purkautuu, demokratian tulee löytää julkisuudelleen uusi kantaja. Sinä ei voi enää toimia kahviloihin, kerhoihin ja lukupiireihin kerääntyneiden porvarien yleisö, joka elää vuorovaikutuksessa parlamenttijulkisuuden kanssa. Seuraten Wolfgang Abendrothin tulkintaa sosiaalivaltiosta Habermas löytää julkisuudelle uuden kantajan yhteiskunnallisista organisaatioista ja 
järjestöistä (ks. Abendroth 1967; Abendrothin merkityksestä vrt. Deppe 2008, 83-138; Habermas 2006). Ratkaisu muistuttaa rakenteellisesti ajatusta kiltasosialismista ja neuvostodemokratiasta. Näin sosialismi on vain toinen nimi loppuun saakka viedylle demokratialle, eli porvarillisen julkisuuden rappio johtaa Habermasilla sosialistisen - sosiaalidemokraattisen - julkisuuden nousun mahdollisuuteen. Tämä on ei-traditionalistinen ja moderni ratkaisu Hegelin perinteen mielessä, koska siinä yhteiskunnan itsesäätely tapahtuu eriytyneen työnjaon, ei orgaanisten yhteisösuhteiden pohjalta. Vastaus demokratian kriisiin löytyy siten demokratisoimalla työelämä ja yhteiskunnalliset organisaatiot.

Luhmannista nuoren Habermasin ratkaisuehdotus on epäonnistunut. ${ }^{\circ}$ Luhmannin järjestelmäteoreettinen vastaveto lähtee Habermasin hegeliläisestä premissistä, mutta radikalisoiden sen. Myös Luhmann ajattelee, että julkisuuden ja yleisen mielipiteen kysymystä on tarkasteltava modernin yhteiskunnan eriytymisen horisontista. Hän lähtee kuitenkin siitä, että kun yhteiskunta on eriytynyt riittävän pitkälle, sillä ei voi olla enää mitään valtion tapaista keskusta (Hegel) tai julkisuuden tapaista yleistä välityselintä (Habermas). Kun kaikki yhteiskunnalliset toimijat edustavat vain erityisintressiä, ketkään yleisöksi kokoontuneet kansalaiset eivät voi puhua yhteisen edun nimissä - eivät porvarit eivätkä sosialistit.

Lippmanniin Luhmannia yhdistää kaksi tekijää, jotka sotivat klassisen liberalismin mukaista demokratiakäytäntöä vastaan kompleksisessa yhteiskunnassa. Jo Lippmann pani paljon painoa sille faktalle, että inmiset lukevat sanomalehteään päivässä suhteellisen lyhyen aikaa. Tämä tarkoittaa sitä, että heidän on valittava sekä lehti, jota lukea, että jutut, joihin keskittyä. Tärkeäksi muodostuvat tällöin ne keinot, joilla lukijoiden niukkaa huomiovarastoa käytetään hyväksi. Luhmann rakentaa yleisen mielipiteen teoriansa vähän samanlaisen idean varaan. Jotta ihmiset saadaan kiinnittämään huomiota poliittisiin asioihin, ne on esitettävä pelkistetysti teemoina, jotka voidaan muotoilla lyhyesti. Yleisen mielipiteen muodostuksessa onkin Luhmannin mukaan ensi sijassa kyse siitä, että sen avulla pyritään kiinnittämään ihmisten huomio tiettyihin politiikan päiväjärjestyksen asialistalle hakeutuviin teemoihin (Luhmann esitti ideansa ns. agenda-setting-tutkimuksen nousun aikoihin; vrt. McComb \& Shaw 1972). Tämä tapahtuu nostamalla kulloinkin esiin ne puheenaiheet, joista keskustelua oletetaan käytäväksi. Yleinen mielipide ei näin tiivistä kansan tahtoa, vaan kiinnittää sen huomion tiettyihin asioihin, joihin sen halutaan ottavan kantaa. Tällä tavalla muodostettu yleinen mielipide ei vielä suoraan sido päätöksentekijöitä, se vain osoittaa sen yleisen liikkuma-alan, jolla toimeenpanovalta voi operoida. Näin Luhmann tulee toista tietä Lippmannin tavoitteeseen: poliittisen päätöksenteon vapauttamiseen yleisen mielipiteen mandaatista.

\section{Lippmannin ja Deweyn ongelmanasettelu tänään: kolme aikalaisdiagnoosia}

Lippmannin ja Deweyn 1920-luvun sananvaihto oli osa laajempaa keskustelua demokratian kriisistä ja julkisuuden rakennemuutoksesta. Liberaalin demokratian toimintakyky massademokratian oloissa puhututti valtiotieteilijöitä Atlantin molemmin puolin, ja Weimarin tasavallan sosiologit sekä sanomalehtitieteilijät pohtivat journalismin ja yleisen mielipiteen kysymyksiä poliittisesti levottomana aikana. Haberma- 
sin ja Luhmannin keskustelun teoriahistoriallinen tausta oli sama, mutta politiikan todellisuus heidän ympärillään oli erilainen. Habermasin Strukturwandel on sodanjälkeisen Saksan liittotasavallan poliittisen kehityksen kärkevä kritiikki, yritys puolustaa sosialistista vaihtoehtoa talousihmeen aikakauden kypsyttämässä konservatiivisessa ilmapiirissä. Luhmann ei hyväksy Habermasin sosialistista nostalgiaa, joka lainaa liberalismin aatteita perustellakseen jälkiliberaalia maailmankuvaa. Luhmannista liberaalia demokratiakonseptia ei voi enää tekohengittää millään tavalla, ei oikealta eikä vasemmalta. Tyynen rauhallisesti on vain hyväksyttävä niin demokratian kuin julkisuuden muutos.

Lippmannin ja Deweyn kolme tässä käsittelemääni kysymystä - demokratia, poliittinen kulttuuri ja julkisuus - ovat tänään yhtä ajankohtaisia kuin satakunta vuotta sitten. Siksi ei ole sattuma, että niihin reagointi on kirvoittanut erilaisia vastauksia politiikan ja joukkoviestinten suhteita tutkivien parissa. Erotan tarkasteluni päätteeksi kolme eri vaihtoehtoa, joiden välillä väittelyä tällä hetkellä käydään. Lista ei ole tyhjentävä, mutta ottaa huomioon tärkeimmät tai ainakin näkyvimmät keskustelukumppanit. Kutsun niitä kaksois-, kulttuuri- ja mediademokraattiseksi lähestymistavaksi.

(1) Kaksoisdemokratia: demokratia poliittisena järjestelmänä. Lippmann näki massademokratian, siis yleisen äänioikeuden aikakauden perusongelmana sen, että yleinen mielipide ei enää voinut toimia poliittisen ohjauksen välineenä. Koska hallitus ei enää kuunnellut eduskuntaa vaan lehdistöä, se tuli saattaa äänenkantaman päähän lehdistöstä. Dewey taas ajatteli, että modernin yhteiskunnan demokratiavaje syntyi kapitalististen intressien liian suuresta vaikutuksesta hallitusvaltaan, mitä tuki kehityksen mahdollisena jarruna toimineen paikallishengen ehtyminen. Siinä, missä Lippmann kuvaa täsmällisesti joukkoviestinnän ja poliittisen järjestelmän suhdetta, Dewey visioi niin yleisesti, että hänen esityksenä pohjalta on mahdoton päätellä, minkälaiseksi hän ajatteli medioiden aseman valtiota ja kansalaisyhteiskuntaa välittävänä instanssina. Kysymys edustuksellisen demokratian elinten ja ulkoparlamentaaristen yhteiskunnallisten liikkeiden suhteesta onkin muodostanut yhden pysyvän teeman 1960-luvun jälkeistä keskustelua.

Jo Habermasin Strukturwandel rakentuu kaksoisdemokratian idealle. Kun porvarillinen yhteiskunta purkautuu, valtion ulkopuoliset yhteiskuntasuhteet politisoituvat. Näin julkisuus ei enää vain välitä poliittisen valtion ja ei-poliittisen yhteiskunnan suhdetta, vaan siitä tulee keino, jolla sosiaalivaltion ohjelma ulotetaan koko yhteiskuntaan. Habermas luopui kuitenkin 1970-luvulla tästä ratkaisusuunnasta ja alkoi kehittää deliberatiivisen, neuvonpitoon perustuvan demokratian teoriaa. Se on joukkoviestintätieteessä ehkä tunnetuin esimerkki kaksoisdemokratiasta, jossa demokratia nojaa kahteen keskukseen tai legitimaation- ja voimanlähteeseen. Yhtäällä on valtio lakia säätävine ja toimeenpanevine elimineen, toisaalla kansalaisyhteiskunta järjestäytymismuotoineen. Julkisuus on kanava, joilla nämä kaksi tulee saattaa intiimiin kosketukseen keskenään. Tämän edellytyksenä on yhtä hyvin se, että julkisuus voi toimia vapaan tarveartikulaation ja mielipiteenmuodostuksen välineenä, kuin se että valtiollinen päätöksenteko herkistyy kansalaismielipiteille (Habermasin täsmällisin julkisuusteoreettinen työ Strukturwandelin jälkeen on Habermas 2008).

(2) Kulttuuridemokratia: poliittinen kulttuuri demokratisoinnin välineenä. Lippmannille poliittinen demokratia oli yksi arvo muiden joukossa, ja näin demokraatiksi ei kasvettu vain vaalimalla poliittisia hyveitä. Yhtä tärkeää oli se, että demokraattinen valtio teki kansalaisilleen mahdolliseksi ei-poliittisten tai sosiaalisten kansalais- 
oikeuksien harjoittamisen. Demokratiatutkimuksen toistuvana empiirisenä löydöksenä onkin ollut, että demokratia on vakainta valtioissa, jotka ovat saavuttaneet tietyn taloudellisen hyvinvoinnin asteen (Buchstein 1997, 130). Dewey taas samasti demokratian ja yhteisöelämän. Näin ratkaiseva poliittinen sosialisaatio sijoittui hänellä kasvokkaissuhteiden ja paikallisyhteisön piiriin. Kummallakaan ei ollut sijaa joukkoviestinnälle poliittisen kulttuurin keskuksena. Kulttuurintutkimus on ottanut 1970-luvulta lähtien tehtäväkseen tämän aukon paikkaamisen.

Kulttuurintutkimuksen tavoitteena on alusta alkaen ollut kulttuurin politisointi, joskin poliittisella kulttuurilla on ollut siinä kaksi eri mallia. Marxilaisessa vaiheessa mallina toimi proletaarisen julkisuuden idea. Ajatuksena oli se, että joukkoviestintä edistää demokraattisempaa, hierarkioista vapaampaa yhteiskuntaa, kun se omaksuu porvarillisten esitystapojen sijasta työväenluokkaisen ilmaisurekisterin. Tätä kautta joukkoviestintä, eritoten televisio pystyy siirtämään vastaanottajiensa maailmaan niitä arvoja, joiden varassa kansanvalta toimii. Jälkimarxilaisessa vaiheessa, 1980luvun ensipuoliskon jälkeen, proletaarisen julkisuuden idea irrotettiin luokkaperustastaan ja siitä tehtiin ylipäätään uuden populaarikulttuurin tunnuspiirre. Näin postmodernin yhteiskunnan poliittisen kulttuurin, kansalaishyveisiin kasvatuksen, ajateltiin tapahtuvan korkeakulttuurisuutta kaihtavan viihdetarjonnan avulla. Poliittisen kulttuurin ydinjännite siis siirtyi porvariston ja työväenluokan hyveiden vastakohdasta korkea- ja populaarikulttuurin hyveiden vastakohtaan (John Fisken tuotannosta löytyvät nämä molemmat vaiheet: ks. Fiske \& Hartley 1978; Fiske 1991). Lähestymistavan erilaisia variaatioita tarjoaa niin kutsuttu representaatio- ja identiteettipolitiikka sekä feministisissä että muissa muodoissaan.

(3) Mediademokratia: julkinen sana suorana demokratiana. Lippmann syytti oman aikansa yleistä mielipidettä siitä, että se oli liberaaleissa demokratioissa ottanut parlamentin paikan hallituksen toiminnan suuntaajana. Jo Aristoteles ajatteli, että kansanvalloissa johtajat joutuvat liehittelemään kansalaisia, mutta nyt hallitusvalta joutui liehittelemään joukkoviestimiä, koska niistä oli tullut yleisen mielipiteen muodostuksen ja levityksen kanava. Dewey ei menettänyt uskoaan paikalliseen yhteisöelämään yleisen mielipiteen tyyssijana, ja siksi hän näki demokratian rapautumisen pikemmin yhteiskunnan kapitalisoitumisessa ja journalismin sensationalisoitumisessa. Lippmannin väite lehdistöstä suoran demokratian väylänä on saanut uutta ajankohtaisuutta mediademokratian ajatuksessa.

Mediademokratiadiagnoosi toistaa sata vuotta vanhemman massayhteiskunnan idean kehittyneen joukkoviestintäjärjestelmän oloissa. Sen lähtökohtana on kaksi teesiä, jotka yhdessä määrittävät mediayhteiskuntaa uudenlaisena yhteiskuntatyyppinä. Ensimmäinen teesi on tuttu varhemmasta poliittisen viestinnän tutkimuksesta. Sen mukaan mediayhteiskunnassa kansalaisten ainoa kosketus politiikkaan tapahtuu joukkoviestinten kautta. Toinen teesi on varsinaisesti uusi postmodernistinen premissi, joka on velkaa muun muassa Guy Debordin (1967) näytös- ja Jean Baudrillardin (1970) kulutusyhteiskunnan teorialle. Sen mukaan ihmisten yleinenkin suhde todellisuuteen käy medioiden kautta, eli heidän maailmasuhteensa on "medioitunut". Tämä muuttaa myös liberaalin demokratian toteutumisehtoja radikaalilla tavalla. Arkielämä ja kansalaisyhteiskunta eivät voi toimia enää inmisten tarpeiden muodostuksen ja ilmaisun itsenäisenä perustana, koska ne ovat mediajulkisuuden ja -tekniikan läpäisemiä. Näin yleinen mielipide ei kykene enää heijastamaan joukkoviestinten ulkopuolista kansalaismielipidettä. Kyse ei ole myöskään deliberatiivisen demokra- 
tian idean mukaisesta vuoropuhelusta kansalaisten ja medioiden välillä, koska edelliset ovat suhteen vastaanottavana puolena. Kyse ei ole sen enempää dialogisuhteesta julkisen sanan ja hallitusvallan kanssa, kahdestakaan syystä. Hallitus saa tietoja kansan suorasta tahdosta vain mediajulkisuuden välityksellä ja - lippmannilaisittain - pystyssä pysyäkseen sen on oltava polkemasta liikaa ei-valtiollisten julkistoimijoiden varpaille. Näin mediayhteiskunnan demokratia toteutuu joukkoviestinten kautta suorana kansanvaltana, jossa poliitikoilla on karismansa (imagonsa) avulla välitön yhteys kansalaisiin ja jossa päivittäisellä kansanäänestyksellä (gallupkyselyillä) mitataan heidän kannatustaan.

Kaksois-, kulttuuri- ja mediademokratianäkemys reagoivat modernin yhteiskunnan demokratian puutteeseen eri tavoin, mikä selittyy niiden erilaisilla taustoilla. Kaksoisdemokratian esikuvana ovat olleet toisen maailmansodan jälkeiset uudet yhteiskunnalliset liikkeet, kuten mustien kansalaisoikeusliike Yhdysvalloissa, opiskelijaliike eri maissa ja vihreiden ympäristöliike varsinkin Länsi-Saksassa. Ne nähdään 180o-luvun synnyttämän työväenliikkeen ja 190o-luvun taitteen naisliikkeen perillisinä, joiden tehtävänä on vaikuttaa parlamentaariseen järjestelmään. Kulttuuridemokratian välitön heräte tulee erityisesti 1960-luvun vastakulttuureista, vaihtoehtoista elämäntapaa etsivien yhteenliittymistä. Nämä - kuten hipit, nuorison alakulttuurit tai erilainen underground - eivät halunneet niinkään vaikuttaa valtioon kuin mahdollistaa elintilaa omalle olemassaolon tyylilleen. Keskeistä on muuttaa puoluepoliittisen järjestelmän ulkopuolista kansalaisyhteiskuntaa tavalla, joka lisää erilaisuuden sietokykyä. Mediademokratian tausta näyttää viittaavan useampaan suuntaan. Yhtäältä sen juuret palautuvat siihen estetisoitumiseen, jonka Walter Benjamin (1991) näki 1930-luvun fasistisen poliittisen julkisuuden avainpiirteenä. Toisaalta se on saanut kimmoketta nimenomaan television asemasta toisen maailmansodan jälkeistä mediakenttää hallitsevana välineenä. Vähäarvoinen lisätekijä ei ole myöskään se yhteiskunnallisten ristiriitojen väheneminen - tai utopian lähteiden ehtyminen (Habermas 1985) - joka on luonnehtinut länsimaisia demokratioita 1970-luvun jälkeen. Mediademokratia pyrkii näin sitomaan kansalaisia politiikkaan näytösluontoisuuden ja audiovisuaalisen interaktiivisuuden keinoin tilanteessa, jossa usko maailman muuttamiseen on hiipunut.

Kaksois-, kulttuuri- ja mediademokratiakäsitys tarjoavat myös keinon valaista nykyisen joukkoviestintätutkimuksen viestintäfilosofista ja poliittista hajontaa. Kaksoisdemokraatit näkevät viestinnän ensisijassa keskusteluna, jonka avulla valtio ja kansalaisyhteiskunta ovat vuorovaikutuksessa keskenään. Näin kiinnostus kohdistuu poliittiseen julkisuuteen, varsinkin journalismiin ja sen kehittämiseen. Kulttuuridemokraateille viestintä on taas olennaisesti itseilmaisua tai keino, jolla inmiset muodostavat minuuttaan niin yksilöinä kuin yhteisöinäkin. Poliittisesta julkisuudesta paino siirtyy kulttuurijulkisuuteen eli - kuten nykyään sanotaan - populaarikulttuuriin. Mediademokraateille viestintä on puolestaan näyttämöllepanoa ja siihen reagointia - siis esteettistä muodonantoa ja kokemusta. Näin poliittinen ja kulttuurinen julkisuus menevät sekaisin, ja kuvien aistimellinen logiikka hallitsee tätä uutta tunnedemokratiaa tai "kollektiivista sensualismia" (Maffesoli 1990). Kun painotukset ovat näin erilaiset, ei ole ihme että se, mikä yhdelle joukkoviestintätieteen suuntaukselle edustaa ihannedemokratiaa, on toiselle epädemokraattista. Mutta juuri tämä vaikeus löytää demokratian, poliittisen kulttuurin ja julkisuuden hahmo, joka vastaisi oman aikamme tarpeita ja mahdollisuuksia, on edellisen vuosisadanvaihteen meille jättämä ongelma. 


\section{Viitteet}

1 Kiitän kommenteista vertaisarvioijina toimineita Risto Kuneliusta ja toista, nimetöntä henkilöä. Palaute on antanut minulle aiheen muuttaa artikkelin kulkua. Esityksen kieliasu on taas kohentunut Marjo Kolehmaisen ja Laura Ruusunoksan neuvoista, joista kiitän.

2 On merkkejä laajemmastakin Lippmannin rehabilitaatiosta joukkoviestintätieteessä, kuten Jansen (2008) ja Schudson (2008) osoittavat. Jansen jättää kuitenkin Lippmannin politiikan ja julkisuuden teorian vähälle huomiolle. Schudsonin päätavoitteena on taas nostaa esiin Careyn Lippmann-kritiikin väärinymmärrykset, ja näin hän käsittelee vain ohimennen Lippmannin demokratiateorian taustaa. (Schudson-vinkistä kiitän Risto Kuneliusta.)

3 Lippmann (1914) esitti vastaavan kokonaisnäkemyksen jo ensimmäisen maailmansodan aattona laatimassaan aikalaisdiagnoosissa.

$4 \quad$ Deweyn Hegel-taustahan on yleisessä tiedossa (ks. esim. Rorty 1982; 1998).

5 Molempien töiden johtopäätöksiä pohjusti Lippmannin huolellinen sisällönerittely New York Timesin Venäjän vallankumousta koskeneesta uutisoinnista vuosilta 1917-1920 (ks. Lippmann \& Metz 1920).

6 Myöhemmin Lippmann (1931) arvioi human interest -journalismin merkityksen myönteisemmäksi, vaikkei luopunutkaan professionaalisen objektiivisen journalismin ihanteestaan.

7 The public and its problems on oudon koukeroinen kirja, kun ottaa huomioon, että se perustuu yleisöluentoihin. Varsinkin journalismikäsityksensä Dewey esittää siinä niukkasanaisesti ja viitteellisesti. Sama asia on ilmaistu selkeämmin Lippmannin The phantom publicin arvostelussa (Dewey 1925, 54).

8 Deweyn pragmatistisen tietoteorian parhaimpana pidetty perustelu on The public and its problems -teoksen ajoilta, vuodelta 1929 (Dewey 1999).

$9 \quad$ Metafysiikassaan Dewey tekee taiteesta erityisenä taitona jopa luonnon korkeimman muodon, joka kumoaa dikotomian luonnon ja kokemuksen, mutta myös teorian ja käytännön välillä (ks. Dewey 1958, 354-393).

10 Kritiikin osuvuuden voi lukea siitä, että 1970-luvun kuluessa Habermas luopui kokonaan Strukturwandelissa esitetystä sosialistisesta utopiasta, joka lunastaisi porvarillisen julkisuuden antaman lupauksen.

\section{Kirjallisuus}

Abendroth, Wolfgang (1967 [1954]). Zum Begriff des demokratischen und sozialen Rechtsstaates im Grundgesetz der Bundesrepublik Deutschland. Teoksessa Abendroth, Wolfgang. Antagonistische Gesellschaft und politische Demokratie: Aufsätze zur politischen Soziologie. Neuwied \& Berlin: Luchterhand, 109-138.

Almond, Gabriel A. (1989). The intellectual history of the civic culture concept. Teoksessa Almond, Gabriel A. \& Verba, Sidnet (toim.). The civic culture revisited. Newbury Park: Sage, 1-36.

Aristoteles (1991). Politiikka. (Teokset VIII). Suom. A. M. Anttila. Helsinki: Gaudeamus.

Aronowitz, Stanley (1993). Is a democracy possible?: The decline of the public in the American debate. Teoksessa Robbins, Bruce (toim.). The phantom public sphere. Minneapolis \& London: University of Minnesota Press, 75- 92.

Asen, Robert (2003). The multiple Mr. Dewey: Multiple publics and permeable borders in John Dewey's theory of the public sphere. Argumentation and Advocacy 39, 174-188.

Baudrillard, Jean (1970). La société de consommation: Ses mythes, se structures. Paris: S. G. P. P.

Bellamy, Richard (2003). The advent of the masses and the making of the modern theory of democracy. Teoksessa Ball, Terence \& Bellamy, Richard (toim.). The Cambridge history of twentieth-century political thought. Cambridge: Cambridge University Press, 70-103.

Benjamin, Walter (1991 [1936]). Das Kunstwerk im Zeitalter seiner technischen Reproduzierbarkeit. Teoksessa Benjamin, Walter. Gesammelte Schriften. Bd. I:2. Frankfurt am Main: Suhrkamp, 471508.

Berg-Schlosser, Dirk (1983). Politische Kultur. Teoksessa Mickel, Wolfgang W. (in Verbindung mit Dietrich Zitzlaff) (toim.). Handlexikon zur Politikwissenschaft. München: Ehrenwirth, 385-388.

Buchstein, Hubertus (1997). Demokratietheorie. Politische Vierteljahresschrift 38: 1, 129-148. 
Carey, James W. (1992a [1975]). A cultural approach to communication. Teoksessa Carey, James W. Communication as culture: Essays on media and society. New York \& London: Routledge, 13-36.

Carey, James W. (1992b [1982]). Reconceiving "mass" and "media". Teoksessa Carey, James W. Communication as culture: Essays on media and society. New York \& London: Routledge. 69-88.

Carey, James W. (1995). The press, public opinion, and public discourse. Teoksessa Glasser, Theodore L. \& Salmon, Charles T. (toim.). Public opinion and the communication of consent. New York \& London: Guilford, 373-402.

Carey, James W. (1997). Community, public, and journalism. Teoksessa Black, Jay (toim.). Mixed news: The public/civic/communitarian journalism debate. Mahwah, N.J.: Lawrence Erlbaum Associates, $1-15$.

Debord, Guy (1967). La société du spectacle. Paris: Buchet \& Chastel.

Deppe, Frank (2003). Politisches Denken im 20. Jahrhundert. Bd. 2: Politisches Denken zwischen den Weltkriegen. Hamburg: VSA.

Deppe, Frank (2008). Politisches Denken im kalten Krieg. Teil 2: Systemkonfrontation, Golden Age, antiimperialistische Befreiungsbewegungen. Hamburg: VSA.

Dewey, John (1922). Public opinion. New Republic, May 3, 286-288.

Dewey, John (1925). Practical democracy. New Republic, December 2, 52-54.

Dewey, John (1954 [1927]). The public and its problems. Athens: Swallow Press; Ohio University Press.

Dewey, John (1958 [1925]). Experience and nature. New York: Dover.

Dewey, John (1998a [1937]). Democracy is radical. Teoksessa Hickman, Larry A. \& Alexander, Thomas M. (toim.). The essential Dewey. Vol. 1: Pragmatism, education, democracy. Bloomington \& Indianapolis: Indiana University Press, 337-339.

Dewey, John (1998b [1939]). Creative democracy - The task before us. Teoksessa Hickman, Larry A. \& Alexander, Thomas M. (toim.). The essential Dewey. Vol. 1: Pragmatism, education, democracy. Bloomington \& Indianapolis: Indiana University Press, 340-343.

Dewey, John (1999 [1929]). Pyrkimys varmuuteen: Tutkimus tiedon ja toiminnan suhteista. Suom. Pentti Määttänen. Helsinki: Gaudeamus.

Fiske, John \& Hartley, John (1978). Reading television. London: Methuen.

Fiske, John (1991). Understanding popular culture. London; New York: Routledge.

Habermas, Jürgen (1962). Strukturwandel der Öffentlichkeit: Untersuchungen zu einer Kategorie der bürgerlichen Gesellschaft. Neuwied: Hermann Luchterhand.

Habermas, Jürgen (1985). Die Krise des Wohlfahrtstaates und die Erschöpfung utopischer Energien. Teoksessa Habermas, Jürgen. Die Neue Unübersichlichkeit: Kleine Politische Schriften V. Frankfurt am Main: Suhrkamp, 141-163.

Habermas, Jürgen (1996). Drei normative Modelle der Demokratie. Teoksessa Habermas, Jürgen. Die Einbeziehung des Anderen: Studien zur politischen Theorie. Frankfurt am Main: Suhrkamp, 277-292.

Habermas, Jürgen (2003). Trois versions de la démocratie libérale. Trad. Christian Bouchindhomme. Le Débat 125, 122-131.

Habermas, Jürgen (2006). Wolfgang Abendroth zum 100. Geburtstag. Teoksessa Urban, HansJürgen; Buckmiller, Michael \& Deppe, Frank (toim.). "Antagonistische Gesellschaft und politische Demokratie": Zur Aktualität von Wolfgang Abendroth. Hamburg: VSA, 21-24.

Habermas, Jürgen (2008). Hat die Demokratie noch eine epistemische Dimension?: Empirische Forschung und normative Theorie. Teoksessa Habermas, Jürgen. Ach, Europa: Kleine politische Schriften XI. Frankfurt am Main: Suhrkamp, 138-191.

Hegel, Georg Wilhelm Friedrich (1970). Grundlinien der Philosophie des Rechts oder Naturrecht und Staatswissenschaft im Grundrisse. (Werke 7). Frankfurt am Main: Suhrkamp.

Heikkilä, Heikki \& Kunelius, Risto (1997). Julkisen journalismin äärellä: Ajatuskokeita pääsyn, keskustelun ja harkinnan käsitteillä. Tiedotustutkimus 20: 4, 5-21.

Hohendahl, Peter Uwe (1978). Kritische Theorie, Öffentlichkeit und Kultur: Anmerkungen zu Jürgen Habermas und seinen Kritikern. Teoksessa Grimm, Reinhold \& Hermand, Jost (toim.). Basis: Jahrbuch für deutsche Gegenwartsliteratur. Bd. 8. Frankfurt am Main: Suhrkamp, 6o-91.

Jansen, Sue Curry (2008). Walter Lippmann, straw man of communication research. Teoksessa Park, David W. \& Pooley, Jefferson (toim.). The history of media and communication research: Contested memories. New York: Peter Lang, 71-112. 
Joas, Hans (1987). Die politischen Ideen des amerikanischen Pragmatismus. Teoksessa Fetscher, Iring \& Münkler, Herfried (toim.). Pipers Handbuch der politischen Ideen. Bd. 5. Neuzeit: Vom Zeitalter des Imperialismus bis zu den neuen sozialen Bewegungen. München \& Zürich: Piper, 611-620 (kirjallisuusluettelo 640).

Krüger, Hans-Peter (2007). John Dewey, Die Öffentlichkeit und ihre Probleme (1927). Teoksessa Brocker, Manfred (toim.). Geschichte des politischen Denkens: Ein Handbuch. Frankfurt am Main: Suhrkamp, 525-539.

Kunelius, Risto (2004). Kokemuksesta julkiseen tietoon: John Deweyn pragmatismia viestinnän tutkijoille. Teoksessa Mörä, Tuomo, Salovaara-Moring, Inka \& Valtonen, Sanna (toim.). Mediatutkimuksen vaeltava teoria. Helsinki: Gaudeamus, 90-118.

Kunelius, Risto (2006). Julkisojen ongelmat: Johdannoksi kirjan The public and its problems suomennokseen. Teoksessa Dewey, John. Julkinen toiminta ja sen ongelmat. Suom. Mika Renvall. Tampere: Vastapaino, 11-32.

Lippmann, Walter (1913). A preface to politics. London: T. Fisher Unwin.

Lippmann, Walter (1914). Drift and mastery: An attempt to diagnose the current unrest. New York: Mitchell Kennerley.

Lippmann, Walter (1922). Public opinion. New York: Harcourt Brace.

Lippmann, Walter (1925). The phantom public. New York: Harcourt Brace.

Lippmann, Walter (1931). Two revolutions in the American press. Yale Review 20: 3, 433-441.

Lippmann, Walter (2008 [1920]). Liberty and the news. Princeton \& Oxford: Princeton University Press.

Lippmann, Walter \& Charles Merz (with the assistance of Faye Lippmann) (1920). A test of the news: An examination of the news reports in the New York Times on aspects of the Russian Revolution of special importance to Americans, March 1917-March 1920. New Republic 296, Supplement, 1-42.

Luhmann, Niklas (1968). Soziologie des politischen Systems. Kölner Zeitscrift für Soziologie und Sozialpsychologie 20, 705-733.

Luhmann, Niklas (1970). Öffentliche Meinung. Politische Vierteljahresschrift 11: 1, 2-28.

Maffesoli, Michel (1990). Au creux des apparences: Pour une éthique de l'esthétique. Paris: Plon.

Malmberg, Tarmo (2004). Porvarillisen julkisuuden keskeneräinen projekti: Jürgen Habermas ja kriittinen mediatutkimus. Teoksessa Teoksessa Mörä, Tuomo, Salovaara-Moring, Inka \& Valtonen, Sanna (toim.). Mediatutkimuksen vaeltava teoria. Helsinki: Gaudeamus, 38-74.

Malmberg, Tarmo (2005). Habermas, porvarillinen yhteiskunta ja julkisuus: Kahden väärinkäsityksen johdosta. Tiedotustutkimus 28: 4-5, 114-117.

Malmberg, Tarmo (2006). Habermas ja teoreettinen julkisuustutkimus: Yritys selittää väärinkäsityksiä. Tiedotustutkimus 29: 2, 121-125.

McCombs, Maxwell \& Donald L. Shaw (1972). The agenda-setting function of mass media. Public Opinion Quarterly 36: 2, 176-187.

Nauta, Lolle (1992). Changing conceptions of citizenship. Praxis International 12: 1, 20-34.

Pappi, Franz Urban (1986). Politische Kultur: Forschungsparadigma, Fragestellungen, Untersuchungsmöglichkeiten. Teoksessa Kaase, Max (toim.). Politische Wissenschaft und politische Ordnung: Analysen zu Theorie und Empirie demokratischer Regierungsweise. Opladen: Westdeutscher Verlag, 279-291.

Peters, John Durham (1989a). Democracy and American communication theory: Dewey, Lippmann, Lazarsfeld. Communication 11: 3, 199-220.

Peters, John Durham (1989b). Revising the 18th-century script. Gannett Center Journal 3: 2, 152-166.

Pietilä, Kauko (1980). Uuden journalismin tutkimus- ja kehittämisprojektista. Tiedotustutkimus 3: 3 , 29-38.

Pietilä, Veikko (1981). Informatiivinen, objektiivinen ja uusi journalismi. Tiedotustutkimus 4: 1, $34-40$.

Pietilä, Veikko (1997). Joukkoviestintätutkimuksen valtateillä: Tutkimusalan kehitystä jäljittämässä. Tampere: Vastapaino.

Pocock, J. G. A. (1995). The ideal of citizenship since classical times. Teoksessa Beiner, Ronald (toim.). Theorizing citizenship. Albany: State University of New York Press, 29-52.

Renvall, Mika (2006). Suomentajan alkusanat. Teoksessa Dewey, John. Julkinen toiminta ja sen ongelmat. Suom. Mika Renvall. Tampere: Vastapaino, 7-10. 
Rorty, Richard (1982). Dewey's metaphysics. Teoksessa Rorty, Richard. Consequences of pragmatism: (Essays, 1972-1980). Brighton: Harvester, 72-89.

Rorty, Richard (1998). Dewey between Hegel and Darwin. Teoksessa Rorty, Richard. Truth and progress: Philosophical papers, Vol. 3. Cambridge: Cambridge University Press, 290-306.

Schudson, Michael (2008). The "Lippmann-Dewey Debate" and the invention of Walter Lippmann as an anti-democrat 1986-1996. International Journal of Communication 2, 1031-1042.

Schumpeter, Joseph A. (1996 [1942]). Capitalism, socialism and democracy. London and New York: Routledge.

Suhonen, Pertti (1998a). Kansan tahto - siis kenen?: Kamppailu yleisen mielipiteen käsitteestä. Teoksessa Kivikuru, Ullamaija \& Kunelius, Risto (toim.). Viestinnän jäljillä: Näkökulmia uuden ajan ilmiöön. Helsinki: WSOY, 171-188.

Suhonen, Pertti (1998b). Kommentteja yleisen ja julkisen mielipiteen käsitteistä. Tiedotustutkimus 21: 3, 97-99.

Taylor, Charles (1985). Humanismus und moderne Identität. Übers. Holger Fliessbach. Teoksessa Michalski, Krzysztof (toim.). Der Mensch in den modernen Wissenschaften. Stuttgart: Klett-Cotta, 117-170.

Wæver, Ole (1998). The sociology of a not so international discipline: American and European developments in international relations. International Organization 52: 4, 687-727. 